\title{
Air quality and odour evaluation on terrains characterized by a complicated odour emission profiles
}

\author{
Izabela Sówka ${ }^{1, *}$ \\ ${ }^{1}$ Wroclaw University of Science and Technology, Unit of Engineering and Protection of Atmosphere, \\ Faculty of Environmental Engineering, 13 Grunwaldzki Square, 50-377 Wrocław, Poland
}

\begin{abstract}
The complexity of describing the very phenomenon of odour nuisance is probably the cause of lack of regulations concerning this topic in the Polish law system as well as standardized odour law in EU. However, in European countries there are solutions regarding this matter. Moreover, methods enabling the evaluation of odour air quality are available. The problem of an authoritative assessment of odour nuisance appears especially when few emission sources characterized by changing conditions and emission profiles and, very often, a complex spatial/topographical structures, also showing locally variable meteorological conditions are located in „vulnerable" places (with many „odour complaints” being recorded there). In conditions similar to the aforementioned the odour situation analysis requires simultaneous usage of several studying methods. In this work are presented: field measurement results and sociological poll results, all carried out for area with several domineering odour emission sources. The research conducted made possible showing the concentration of various odour types and their sources for the researched area, which later on enabled to undertake action aiming at reducing odour nuisance.
\end{abstract}

\section{Introduction}

The EU odour regulations that are in effect determine diversely the criteria and acceptable values, mainly in odour emission $\left(\mathrm{ou}_{\mathrm{E}} / \mathrm{s}\right)$, odour concentration $\left(\mathrm{ou}_{\mathrm{E}} / \mathrm{m}^{3}\right)$, as well as the methods, reference models and techniques of controlling and preventing odour nuisance [12]. This fact implies that not uniform solutions are applied in the EU, apart from the dynamic olfactometry methods defined in Poland by regulations in the PN-EN 13725:2007 norm [3]. These are used in assessing the odour impact of objects emitting odorous substances [3-5].

The research carried out as a part of measurements and analyses concerning OIC (odour impact criteria) includes, among other things, determining the concentration of odour (C), the intensity of the odour (I), the character of the odour $(\mathrm{C})$, the offensiveness of the odour (O) and the persistence of the odour (P), which is what the so called CICOP stands for, and allow using criteria comprised of: frequency of the odour exposure $(\mathrm{F})$, intensity of the odour (I), duration of exposure to the odour (D), offensiveness of the odour $(\mathrm{O})$, tolerance and

\footnotetext{
*Corresponding author: izabela.sowka@pwr.edu.pl
} 
expectation of the exposed subjects (location - L) - the so called FIDOL [1-2] [6-7]. Therefore, diversified research method can be used to determine the 'characteristics' of the odour air quality, the scale and the range od of odour impact and odour nuisance, and if there are several odour emission sources of different character in Polish conditions, a field and sociological study is especially preferred [8-9], for simultaneously applying both of them makes it possible to identify and determine the share of individual odour emission sources in shaping the odour air quality.

This work aimed to evaluate the usefulness of field an sociological studies in determining the part of separate odour emission sources in shaping the odour air quality of a city area and the terrain that is directly adjacent, marked by several emission sources encompassing housing, municipal and industrial management.

\section{A preliminary characteristic of odour air quality on the studied area}

The area examined is inhabited by more than 39057 people (as of 2016) and located in the southern part of central Poland. The analysis of the few-years-old history of complaints about odour nuisance pointed out several domineering odour emission sources, including a wastewater treatment plant, a municipal waste plant and industrial plants. Because of this, a team of experts and field inspectors, whose olfactory sensibility had been tested according to the PN-EN 13725:2007 regulation, carried out the field reconnaissance including: the areas and points near the addresses of complaints filed by the inhabitants and on sites potentially being odour emission sources (fig. 1-2). On the grounds of visits to chosen objects, alongside the obtained technological information, main emission sources and the character of emitted odours were identified. In later works, these were also noted down by the inhabitants in the so-called Odour Observation Diaries and determined by field studies in the so-called measurement gird. On the analysed sites (table 1) the characters of odours were given the following symbols: A - no odour, B-I - identified odour types, J - other odour. The following smell types were determined to domineer: industrial, glue (characteristic of industrial plant no. 1) 'wastewater' and 'wastewater-industrial' (characteristic mostly of the wastewater treatment plant), as well as 'municipal waste' and 'composting' odour (characteristic of the waste management plant) as described by [9]. Additionally, it was observed that on the industrial plant no. 4 the dominating 'wastewater-industrial' smell originated in periodical transport of tanks of sewage through the plant.

Therefore, the field reconnaissance made it possible to characterise the studied area in the aspect of odour emission and to inventory its sources. The identified source and the smell types typical of them were included in both sociological research (the Odour Observation Diaries) conducted between 1.06.2017 r. and 31.08.2017 r. as well as during the field research carried out between 25 and 28 June and between 31 August - 3 September 2017. 


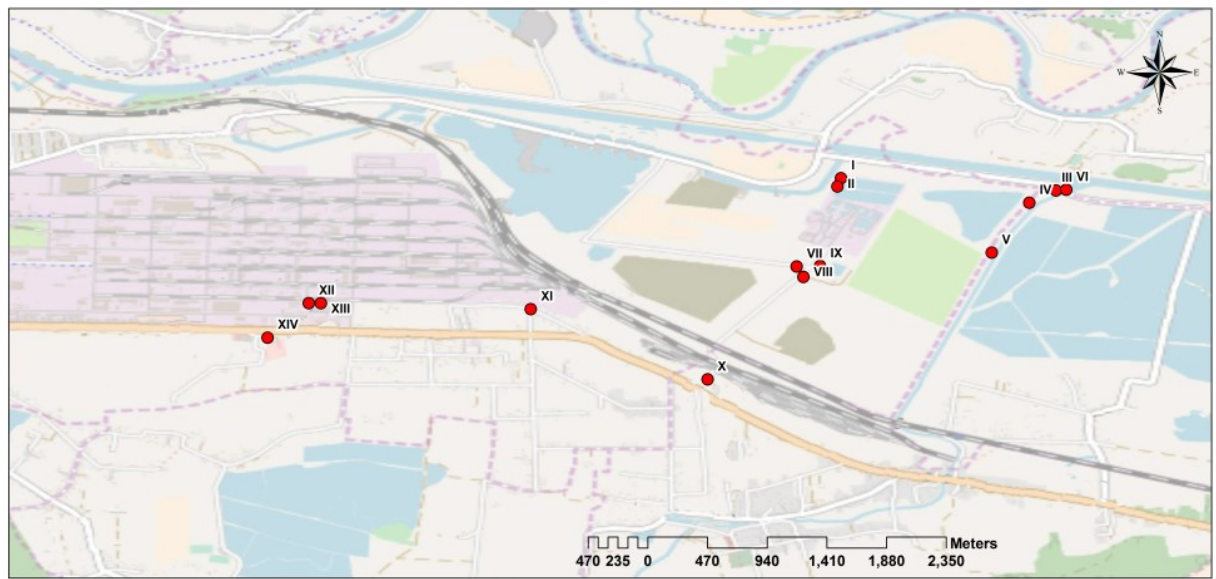

Fig. 1. The area of measurement reconnaissance no. 1 with measurement points marked in the studied area (data source for base map layout: [10]).

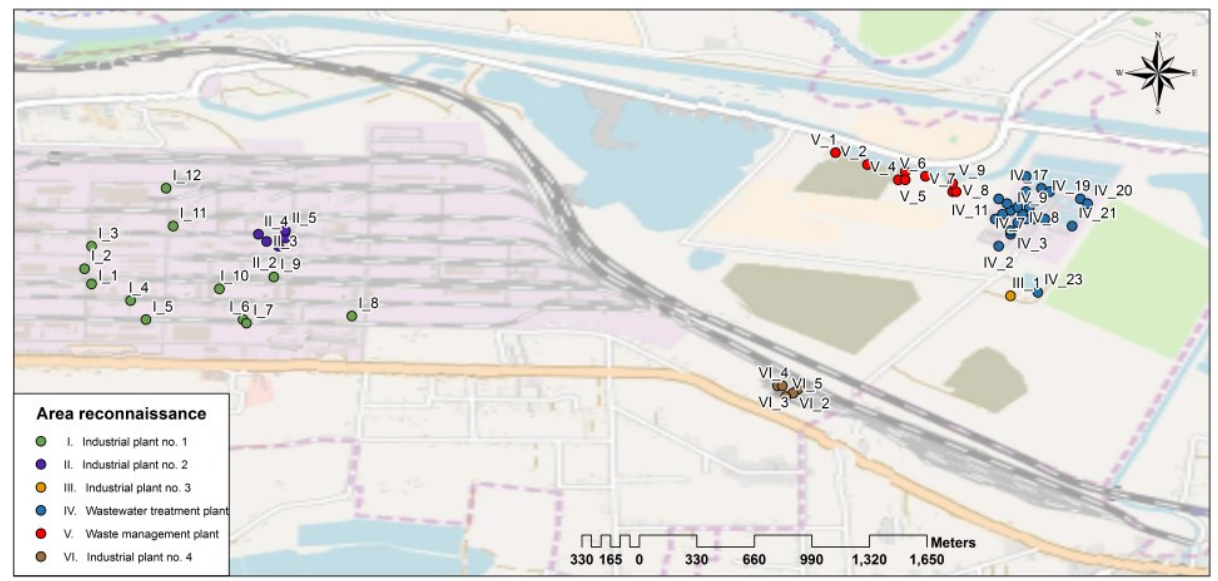

Fig. 2. The area of measurement reconnaissance no. 2 with measurement points marked in the studied area (data source for base map layout: [10]).

Table 1. Activities identified as being the source of odour emission (labelled according to Fig. 2.) and the character of the emitted odour

\begin{tabular}{|c|c|c|}
\hline $\begin{array}{c}\text { Symbol of } \\
\text { plant/activity }\end{array}$ & Name of the activity & Odour type \\
\hline I & Industrial plant No. 1 & $\begin{array}{c}\text { Industrial (characteristic / dominating sector } \\
\text { of research) (B) } \\
\text { Smell of glue (C) }\end{array}$ \\
\hline II. & Industrial plant No. 2 & $\begin{array}{c}\text { Wine (D) } \\
\text { Acetic acid (E) }\end{array}$ \\
\hline III. & Industrial plant No. 3 & No odour was observed \\
\hline IV. & $\begin{array}{c}\text { Wastewater treatment } \\
\text { plant }\end{array}$ & $\begin{array}{c}\text { Wastewater (F) } \\
\text { Wastewater-industrial (G) }\end{array}$ \\
\hline V. & $\begin{array}{c}\text { Waste management } \\
\text { plant }\end{array}$ & $\begin{array}{c}\text { Municipal waste (H) } \\
\text { Composting (I) }\end{array}$ \\
\hline VI. & Industrial plant No. 4 & Wastewater-industrial (G) \\
\hline
\end{tabular}




\section{Determining the influence of selected odour emission sources on the air quality and odour of the studied area}

Figures Fig. 3. and Fig. 4. presents the results of analyzing the data from Odour Observation Diaries in the aspect of the inhabitants' assessment of the area of sources and of the types of odours, whereas Fig. 5. displays the average intensity values of selected odour types (B-J) obtained in two measurement series.

The conducted analyses imply that in a major number of cases the source was to be a 'wastewater treatment plant' (Fig. 3.). Respondents most frequently described the smell as 'industrial-sewage' and 'sewage' (Fig. 4.).

The spatial analysis of field research results involved mean smell intensity and odour sources (Fig. 5.). From it one can draw conclusions than at most measurement points the predominating smell type was the so-called 'other' odour. Thus, the 'other' odour category was also analysed and, as it turned out, was comprised mostly of biogenous (grass) smell and fume smell.

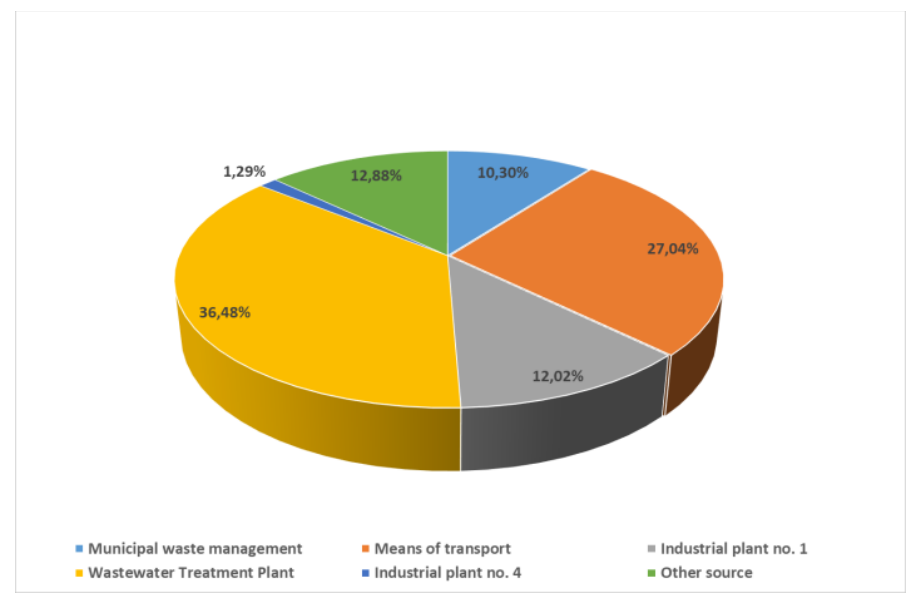

Fig. 3. Odour sources indicated by the inhabitants.

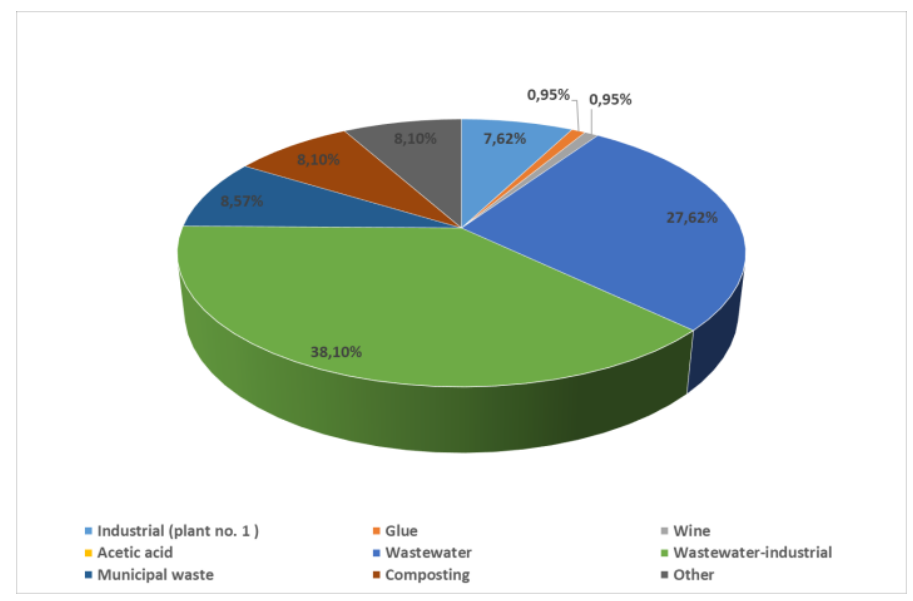

Fig. 4. Types of odour indicated by the inhabitants. 
One should emphasize that at some measurement points (Fig. 5.) 'wastewater', 'industrial' (characteristic for plant no.1), 'glue' and 'municipal waste' odours influenced mostly the odour air quality, which can lead to the number of odour complaints filed by the inhabitants.

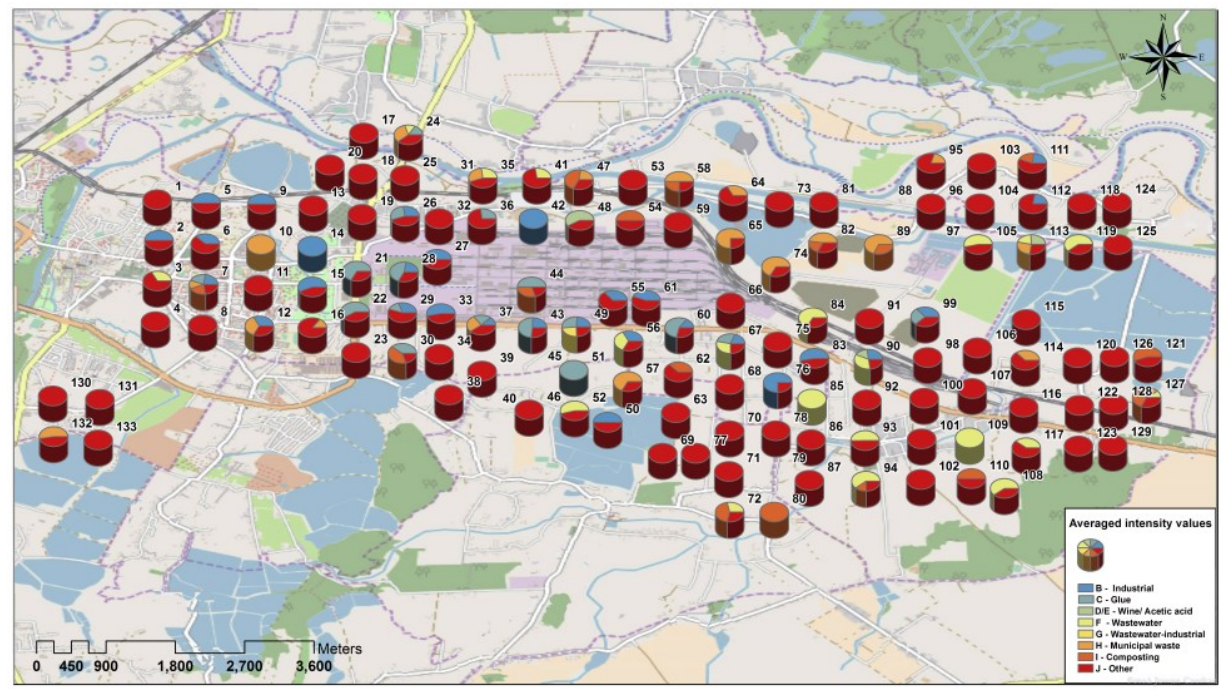

Fig. 5. Mean intensity values of selected odours types obtained in two measurement series (data source for base map layout: [10]).

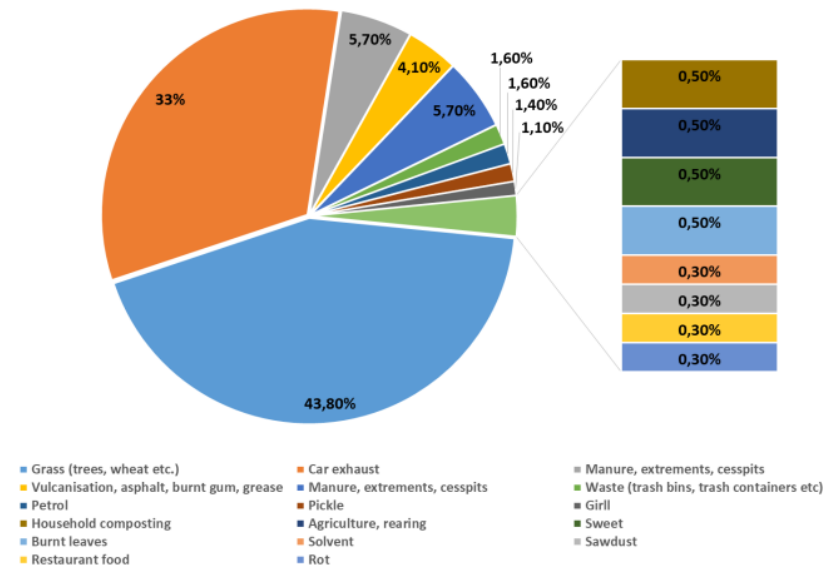

Fig. 6. Results of analysing the odours described as 'other'.

\section{Summary}

Assessing odour impact of odour-emitting objects and odour nuisance is hindered by, among other things, lack of unified regulations concerning odours in the EU and lack of direct regulations concerning this matter in Poland, especially where there are several objects worsening, even periodically, the odour air quality and reinforcing odour nuisance. It seems optimal that in cases like this several research methods be used simultaneously, including field and sociological research. Analyses of this sort were conducted for an area dominated 
by the influence of several odour emission sources and allowed to point out the share of different smell kinds and their sources in the studied area, which in turn later enabled taking action aiming at reducing odour nuisance.

\section{References}

1. I. Sówka , L. Karski L., E3S Web of Conferences, ISSN 2267-1242, 28, 1-8 (2018)

2. I. Sówka, L. Karski L., Przegląd Komunalny 3, 8-10 (2018)

3. PN-EN 13725:2007 - JAKOŚĆ POWIETRZA: Oznaczanie stężenia zapachowego metodą olfaktometrii dynamicznej

4. A. Kulig, J. Zwoździak, M. Szklarczyk, I. Sówka, Propozycja metodyki oceny zawartości substancji zapachowo czynnych $w$ powietrzu (Polish Ministry of Environment, 2011)

5. I. Sówka. Metody identyfikacji odorotwórczych gazów emitowanych z obiektów przemystowych (Publishing House of Wroclaw University of Science and Technology, 2011)

6. V. Naddeo, V. Belgiorno, T. Zarra, Procedures for odour impact assessment in: Odor Impact Assesmnent Handbook (John Wiley\&Sons Ltd., 187- 203, 2013)

7. Brancher M., K.D. Griffiths, D. Franco, H. de Melo Lisboa, Chemosphere 168, 15311570 (2017)

8. I. Sówka, Ł. Pachurka, Y. Bezyk, A. Grzelka, U. Miller, Environmental Protection and Natural Resources 28, 16-21 (2017)

9. I. Sówka, U. Miller, Y. Bezyk, A. Nych, A. Grzelka, Ł. Dąbrowski: E3S Web of Conferences, ISSN 2267-1242, 45, 1-8 (2018)

10. OpenStreetMap.org. Available from : https://github.com/openstreetmap/openstreetmap-website/tree/master/config/locales 